\title{
Marine Neurotoxins: A Double- Edged Sword in Food Industry and Brain Research
}

\author{
Liying Huang ${ }^{1}$, Likun Gong ${ }^{2}$, Xiang Xue ${ }^{3^{*}}$, Yuexing Zhang ${ }^{4^{*}}$ \\ ${ }^{1}$ Marine Fisheries Research Institute of Zhejiang, Marine and Fishery Institute \\ of Zhejiang Ocean University, Zhoushan 316021, China; \\ ${ }^{2}$ Center for Drug Safety Evaluation and Research, Shanghai Institute of \\ Materia Medica, Chinese Academy of Sciences, Shanghai 201203, China; \\ ${ }^{3}$ Department of Molecular and Integrative Physiology, University of Michigan \\ Medical School, Ann Arbor, Michigan, USA; \\ ${ }^{4}$ Marine Science and Technology College of Zhejiang Ocean University, \\ National Engineering Research Center For Marine Aquaculture, Zhoushan \\ 316022, China.
}

Corresponding to: Xiang Xue, Ph.D., Department of Molecular and Integrative Physiology, University of Michigan Medical School, Ann Arbor, Michigan, 48109, USA. Email:xxue@umich.edu;

also Corresponding to: Yuexing Zhang, Marine Science and Technology College of Zhejiang Ocean University, National Engineering Research Center For Marine Aquaculture, Zhoushan 316022, China. Email: yuexing.zhang@zjou.edu.cn.

\begin{abstract}
Marine organisms are important food resource for human. Diversified neurotoxins have been found in marine organisms. In order to effect effectively in ocean, marine neurotoxins are often multiplied potent than other toxins. Therefore the safety of marine products is critical for human health. Here we summarize the current potent marine neurotoxins and their derivatives based on their latest application in neuron science research. Their toxicity mechanism is also discussed. Most of the toxins specifically act on ion channels including $\mathrm{Na}^{+}, \mathrm{K}^{+}$, $\mathrm{Ca}^{2+}$ channels, a few interact with receptors like glutamate receptor or nicotinic acetylcholine receptors thus can have effect on neurons. They are frequently used as agonist or antagonist either blockade the channel or excite the potential. Overall, it is worthwhile to make use of this double-edged sword pharmacologically and scientifically.
\end{abstract}

Keywords: marine toxin, neurotoxicity, voltage-gated ion channels, sea food safety

\section{INTRODUCTION}


Marine animals have unique way to defense because of their soft body, relatively immobile and lack of obvious physical strength. Living in an enormous and diverse space provided by the ocean, they may accumulate and use a variety of toxins for their protective purposes. The toxins vary from small molecules to peptides, and display unique chemical and biological features of scientific interest. Due to environmental change and pollutions, possibly for the purpose of surviving, there are more neurotoxins released by marine organisms ${ }^{[1]}$. The released neurotoxins are harmful for human and animals that eat them. There are reports that seafood has been recalled due to toxins that cause brain damage. Thus it is important to detect the presence of neurotoxins in marine food industry ${ }^{[2]}$. On the contrary, the potent neurotoxicity can serve as useful research tools, the substance's unique structure can also serve as molecular models for the design of new drugs and pesticides ${ }^{[3]}$. This paper summarizes some of the new advances in known neurotoxins and specifically their application in neuron science research.

Marine neurotoxins cause neurotoxicity mainly by interacting with voltage-gated $\mathrm{Na}^{+}, \mathrm{K}^{+}$and $\mathrm{Ca}^{2+}$ channels and modulating the flux of these ions into cells, resulting in adversely affected functions in both developing and mature nervous tissue ${ }^{[4,}$

${ }^{5]}$. Because marine neurotoxins specifically target neural components, it is important to use them in the research of animal model for brain disorders ${ }^{[6]}$. Pseudomonas aeruginin as representation of polyetropoid toxins produced by dinoflagellates, is a voltage-dependent $\mathrm{Na}^{+}$channel agonist that increases the permeability of $\mathrm{Na}^{+}$to the cell membrane, resulting in strong depolarization, causing neuromuscular excitability change. While the others are produced by marine bacteria and actinomycetes toxin, like tetrodotoxin is $\mathrm{Na}^{+}$channel blockers, binding to the outside of $\mathrm{Na}^{+}$channel, thus blocking the passage of $\mathrm{Na}^{+}$. Some bacteria and algae produced by the stone nectar is also $\mathrm{Na}^{+}$ channel blockers, causing neuromuscular signal transmission failure, leading to paralytic poisoning. In addition, some of the peptides produced by blue bacteria can also make $\mathrm{Na}^{+}$channel inactivation, which cause strong neurotoxin. $\mathrm{K}^{+}$channel inhibitors are also an important group of natural products found in marine neurotoxins. There are other neurotoxins acting on the $\mathrm{Ca}^{2+}$ channel, with both effects of block and excitement. Moreover, some compounds or peptides can bind receptors like glutamate receptor or Nicotinic acetylcholine receptors thus can have effect on neurons.

Table 1. Summary of the marine neurotoxins

\begin{tabular}{|c|c|c|c|}
\hline Neurotoxin & Molecular target & Organisms & Application \\
\hline $\begin{array}{l}\text { Tetrodotoxin } \\
\text { (TTX) }\end{array}$ & $\mathrm{Na}+$ channel & Puffer fish & $\begin{array}{l}\text { 1. Selectively inhibit } \mathrm{Na}+ \\
\text { 2. Analgesic }\end{array}$ \\
\hline $\begin{array}{l}\text { Ciguatoxin } \\
(\mathrm{CTX})\end{array}$ & $\mathrm{Na}+$ channel & $\begin{array}{l}\text { Gambierdiscus } \\
\text { toxicus }\end{array}$ & 1. Agonist of voltage-dependent $\mathrm{Na}+$ channels \\
\hline $\begin{array}{l}\text { Azaspiracid-1 } \\
(\text { AZA-1) }\end{array}$ & $\mathrm{Na}+$ channel & Algae & $\begin{array}{l}\text { 1. Inhibit the activity of } \mathrm{Na}+\text { channels with glutaric acid } \\
\text { 2. hERG channel blocker }\end{array}$ \\
\hline
\end{tabular}

Sea anemone $\mathrm{Na}+$ channel, $\mathrm{K}+$ Sea anemones

1. ATX-2, Calitoxin and anthopleurin selectively act on the $\mathrm{Na}+$ channels

2. BDS-I/II specifically inhibit Kv3-family K+ channels

3. Kaliseptine and kalicludines selectively blockade $\mathrm{K}+$ channels 


\begin{tabular}{|c|c|c|c|}
\hline \multirow[t]{5}{*}{$\begin{array}{l}\text { Conotoxin } \\
(\mathrm{CTX})\end{array}$} & \multirow{5}{*}{$\begin{array}{l}\text { Na+ channel, } \\
\mathrm{Ca} 2+\text { channel, } \\
\text { AchR }\end{array}$} & \multirow[t]{5}{*}{ Cone snails } & $\begin{array}{l}\text { 1. } \mu-C T X, \delta-C T X \text { specifically suppresses voltage- } \\
\text { sensitive } \mathrm{Na}+\text { channels }\end{array}$ \\
\hline & & & 2. $\omega$-CTX selectively blockade Ca2+ channel \\
\hline & & & $\begin{array}{l}\text { 3. } \alpha-C T X \text { blockades neuronal chondrocyte acetylcholine } \\
\text { receptors (AchR) }\end{array}$ \\
\hline & & & 4. Analgesics \\
\hline & & & 5. Pain relief \\
\hline Saxitoxin & $\mathrm{Na}+$ channel, $\mathrm{K}+$ & Dinoflagellates & 1. Selective $\mathrm{Na}+$ channel blocker \\
\hline$(\mathrm{STX})$ & $\begin{array}{l}\text { channel, Ca2+ } \\
\text { channel }\end{array}$ & & 2. Act on $\mathrm{K}+$ and $\mathrm{Ca} 2+$ channels \\
\hline $\begin{array}{l}\text { Palytoxin } \\
\text { (PLTX) }\end{array}$ & $\begin{array}{l}\mathrm{Na}+\text { channel, } \mathrm{K}+ \\
\text { channel }\end{array}$ & $\begin{array}{l}\text { Palythoa, } \\
\text { Ostreopsis }\end{array}$ & 1. Act on the $\mathrm{Na}+-\mathrm{K}+-\mathrm{ATPase}$ \\
\hline $\begin{array}{l}\text { Domoic acid } \\
\text { (DA) }\end{array}$ & $\begin{array}{l}\text { Glutamate } \\
\text { receptor }\end{array}$ & Algae & 1. AMPA/kainate receptor agonist \\
\hline $\begin{array}{l}\beta-\mathrm{N}- \\
\text { methylamino- } \\
\text { L-alanine } \\
\text { (BMAA) }\end{array}$ & $\begin{array}{l}\text { Glutamate } \\
\text { receptors }\end{array}$ & Mollusks & 1. Act glutamate receptors \\
\hline $\begin{array}{l}\text { Nereistoxin } \\
(\mathrm{NTX})\end{array}$ & $\begin{array}{l}\text { Nicotinic } \\
\text { acetylcholine } \\
\text { receptors }\end{array}$ & Annelid worm & $\begin{array}{l}\text { 1. Selectively blockade nicotinic receptors } \\
\text { 2. Insecticide }\end{array}$ \\
\hline Anabaseine & $\begin{array}{l}\text { Nicotinic } \\
\text { acetylcholine } \\
\text { receptors }\end{array}$ & Nemertines & 1. Acetylcholine receptor agonist \\
\hline
\end{tabular}

\section{CLASSIFICATION OF MARINE NEUROTOXINS}

According to marine neurotoxins' various toxicity mechanism, we grouped them in this review we group them based on the channels/receptors they interact with. However, some toxins have multiple targets, we addressed them in each category. They are summarized in table 1 .

\subsection{Marine neurotoxins interacting with $\mathrm{Na}+$ channel}

The voltage-gated $\mathrm{Na}^{+}$channel is crucial for normal neuronal functioning ${ }^{[7]}$. The components of the channel are integral membrane proteins scattered along the axon of a neuron and each one has four domains. When a voltage changes or ligand binds in the right way, opening of the voltage-gated $\mathrm{Na}^{+}$ channel occurs. It is very important that these $\mathrm{Na}^{+}$ channels are functioning properly, as they are essential for the propagation of the action potential. Without this ability, the nerve cell can not transmit signals and the part of the body that it innervates is disconnected from the nervous system. This may lead to paralysis of the affected part. Many marine neurotoxins can specifically or non-specifically act on $\mathrm{Na}^{+}$channel.

Tetrodotoxin (TTX), a specific blocker of a voltage-sensitive $\mathrm{Na}^{+}$channel, is isolated from puffer fish and has a high degree of $\mathrm{Na}^{+}$passage for excitatory cell membranes such as nerves, muscles, and Pujinye's fibers Specificity ${ }^{[8,9]}$. The marine flatworm Planocera multitentaculata is a 
known TTX-bearing organism, and is suspected to be a TTX supplier to puffer fish ${ }^{[10]}$. TTX is an important tool for the identification, isolation, and study of $\mathrm{Na}^{+}$channels because of its high selectivity and high affinity for blocking $\mathrm{Na}^{+}$channels on the neurohormonal membrane ${ }^{[11-13]}$. However, it is more interestingly that TTX's mechanism of action differs from terrestrial found toxins. It selectively inhibits $\mathrm{Na}^{+}$passage through the neural cell membrane at very low concentrations but allow $\mathrm{K}^{+}$to pass through. This property is extremely useful for neurobiology and pharmacological studies. TTX is one of the most peculiar natural products of small molecules found in the nature today, and has great potential in drug development ${ }^{[14]}$. TTX was originally used to treat neuralgia in patients with leprosy as a strong analgesic with relatively slow and long lasting, but no addiction. It is thousands times more potent than usual anesthetic drugs with local anesthetic effect and has significant antiarrhythmic activity. TTX has seven natural derivatives, they selectively blockade function of the $\mathrm{Na}^{+}$channel on cell membrane. However, due to their great toxicity, and lack of pharmacokinetic data, they have not been widely used. Thus derivatives that can have reduce toxicity but preserve the potential blocking effect would be of great significance.

Ciguatoxin (CTX) is derived from the genus Gambierdiscus toxicus and all fish that eat this algae accumulate CTX ${ }^{[15]}$. CTX toxicity is 100 times stronger than TTX. CTX is a new agonist of voltagedependent $\mathrm{Na}^{+}$channels that binds to the channel receptor site $\mathrm{VI}$ and increases the permeability of $\mathrm{Na}^{+}$to excite the cell membrane, causing strong depolarization, resulting in changes in neuromuscular excitability, inducing a series of pharmacological and toxicological effects ${ }^{[16-18]}$. Three types of CTX, Pacific cigarettes, Caribbean ciguatoxin, and Indian ciguatoxin have been found ${ }^{[19]}$.

Azaspiracid-1 (AZA-1) is an algal toxin that accumulates in edible mussels. It can induce diarrhetic shellfish poisoning (DSP)-like disease in humans or neurotoxicological symptoms and death in mice ${ }^{[20]}$. The toxin is able to inhibit neurological signaling in spinal cord neuronal networks, in young cerebellar granule cell cultures and in primary neocortical neurons. At high concentrations it acts as a human ether-a-go-go related gene (hERG) potassium channel blocker ${ }^{[21]}$. In the presence of glutaric acid, AZA-1 at nanomolar concentration could inhibit the activity of $\mathrm{Na}^{+}$channels in vitro. AZA-1 exposure induces an early differentiation phenotype followed by a later cell death in PC12 cells ${ }^{[22]}$. The differentiated appearance coincides with down-regulation of a specific peripherin isoform, a neuronal specific intermediate filament protein ${ }^{[22]}$.
Sea anemone is a group of neurotoxins isolated from shoreline anemone Palvthora toxicus, $P$. vestitus, $P$. mamillosa, and $P$ caribaeorum ${ }^{[23-25]}$. One sub family of sea anemone toxins acts on the $\mathrm{Na}^{+}$channel while another subfamily acts on the $\mathrm{K}^{+}$ channel ${ }^{[25]}$. ATX-2 is one of the anemone toxin, which can selectively act on the $\mathrm{Na}^{+}$channels of the cell membrane ${ }^{[26-28]}$. It is also an effective tool for studying myocardium and nerve membrane excitations. Calitoxin and anthopleurin also belong to the sodium channel toxin family ${ }^{[29]}$. These neurotoxins bind specifically to the sodium channel, thereby delaying its inactivation during signal transduction, resulting in strong stimulation of mammalian cardiac muscle contraction. Calitoxin 1 has been found in neuromuscular preparations of crustaceans, where it causes massive neurotransmitter release, causing firing of the axons ${ }^{[29]}$.

Conotoxin (CTXs) are small peptides toxins consisting of 10 to 30 amino acid residues ${ }^{[30]}$. They are the smallest neurotransmitter neurotoxins found so far. They can be classified into $\alpha, \omega, \mu, \delta$ and other subtypes, each subtype can still be subdivided. $\mu$-CTX specifically suppresses voltage-sensitive $\mathrm{Na}^{+}$channels in the activation phase ${ }^{[31]}$. While ठ-CTX specifically suppresses voltage-sensitive $\mathrm{Na}^{+}$ channel in the non-activated phase, extending the duration of action potential ${ }^{[32]}$. Clinically CTX are used as specific diagnostic reagents. Additionally, CTXs also used as analgesics with a curative but non addictive effect. CTXs are interesting molecules with a diverse human therapeutic activities, such as anti-nociceptive, antiepileptic, cardio- and neuroprotective.

Saxitoxin (STX) is a neurotoxin naturally produced by certain species of marine dinoflagellates and freshwater cyanobacteria ${ }^{[33]}$. STX is associated with paralytic shellfish poisoning (PSP), together with its derivatives they are often referred to as "PSP toxins" [34]. Among the derivatives GTX-III is the only one exhibits comparable toxicity to that of STX. It acts as a selective $\mathrm{Na}^{+}$channel blocker, preventing normal cellular function and leading to paralysis ${ }^{[35]}$. STX and its derivatives are also known to act on $\mathrm{K}^{+}$and $\mathrm{Ca}^{2+}$ channels ${ }^{[36]}$.

Palytoxin (PLTX) is a potent non-protein marine compound produced by corals of the genus Palythoa and by dinoflagellates of the genus Ostreopsis ${ }^{[37]}$. Several PLTX analogues have been identified so far, either from Palythoa or from Ostreopsis ${ }^{[38]}$. PLTX acts on the $\mathrm{Na}^{+}-\mathrm{K}^{+}$- ATPase (sodium pump), thus allows passive transport of both $\mathrm{Na}^{+}$and $\mathrm{K}^{+}$, resulting in an imbalance of the ion gradient that is essential for most cells. This feature enables PLTX be a powerful tool in neuron research. 


\subsection{Marine neurotoxins interacting with $\mathrm{K}^{+}$channels}

Voltage-gated $\mathrm{K}^{+}$channels are transmembrane channels specific for $\mathrm{K}^{+}$and sensitive to voltage changes in many cells membrane potential ${ }^{[39]}$. They play a crucial role in repolarizing the membrane after the initiation of an action potential. They are also involved in physiological processes, such as neuronal excitability, muscle contraction, neurotransmitter release. The $\mathrm{Kv} 3 \mathrm{~K}^{+}$channels, with features of ultra-rapid gating and high activation threshold, are essential for high-frequency firing in many CNS neurons. More important, the Kv3.4 subunit has been implicated in the major CNS disorders such as Parkinson's and Alzheimer's diseases. Therefore, it is implicated that selectively targeting this subunit might have a therapeutic utilization application.

Sea anemone venom is an important source of bioactive compounds used as tools to study the pharmacology and structure-function of voltagegated $\mathrm{K}^{+}$channel ${ }^{[40]}$. These neurotoxins can be divided into four different types, according to their structure and mode of action. Sea anemone neurotoxin family includes the antihypertensive and antiviral proteins BDS-I (P11494) and BDSII (P59084) expressed by Anemonia viridis (previously Anemonia sulcata). BDS-I is used as a specific inhibitor of $\mathrm{Kv} 3$-family $\mathrm{K}^{+}$channels ${ }^{[41]}$. Both peptides are known to specifically blockade the Kv3.4 potassium channel, and markedly inhibits current through Kv3.1 and Kv3.2 channels, thus bring about a decrease in blood pressure and possible application in degenerative disorders ${ }^{[42]}$. Because of the effect on $\mathrm{K}^{+}$channels, Sea anemones neurotoxins have been widely used as pharmacological tools. Furthermore, some of the toxins are now useful drugs for the diagnosis and treatment of autoimmune diseases ${ }^{[43]}$. Kaliseptine and kalicludines isolated from Anemonia viridis is in the $\mathrm{K}^{+}$channel toxin family too ${ }^{[44]}$. Kaliseptine binds to the same receptor site as dendrotoxin and kalicludines, function as an efficient $\mathrm{K}^{+}$channel inhibitor.

\subsection{Marine neurotoxins interacting with $\mathrm{Ca}^{2+}$ channels}

Voltage-gated $\mathrm{Ca}^{2+}$ channels are heteromeric proteins composed of 5 subunits ${ }^{[45]}$. These channels mediate $\mathrm{Ca}^{2+}$ influx into the cell following membrane depolarization. Two distinct classes of $\mathrm{Ca}^{2+}$ channels are generally recognized: the high voltage-activated (HVA) and low voltage-activated (LVA) channels. Each class is characterized by the degree of depolarization required for channel activation, a biophysical property that is largely determined by the $\alpha 1$ subunit. $\mathrm{Ca}^{2+}$ channel is widely expressed throughout the body, particularly in excitable and secretory cells, $\mathrm{Ca}^{2+}$ is a ubiquitous signaling molecule critical to a wide range of physiologic processes in virtually all cell types, including neurons. Thus $\mathrm{Ca}^{2+}$ channels are targets for numerous ligands including marine naturally occurring peptide toxins. Some of these peptide toxins are invaluable tools for studying the structure and function of $\mathrm{Ca}^{2+}$ channels and have potential therapeutic applications ${ }^{[46]}$.

Among the super family, $\omega$-CTX specifically blockade neuronal enamel presynaptic voltagesensitive $\mathrm{Ca}^{2+}$ channel ${ }^{[47,48]}$. They are found in the venom of piscivorous (fish hunters), vermivorous (worm hunters), and molluscivorous (mollusk hunters) cone snails. The most extensively analyzed $\omega$-conotoxin to date is $\omega$-MVIIA, which blockades CaV2.2 ion channels. This conotoxin has been approved by the FDA as a non-opioid analgesic peptide against long-term neuropathic pain in human, under the commercial name of Prialt ${ }^{[49]}$. $\omega$-CTX solidified a role in pain management with the approval of ziconotide ${ }^{[50]}$. Ziconotide acts as a selective $\mathrm{N}$-type voltage-gated $\mathrm{Ca}^{2+}$ channel blocker. This action inhibits the release of pro-nociceptive neurochemicals like glutamate, CGRP, and substance $P$ in the brain and spinal cord, resulting in pain relief. With very similar structure to $\omega-C T X$, RsXXIVA was isolated from the venom duct of Conus regularis and it showed inhibition on CaV2.2mediated calcium currents in rat superior cervical ganglion (SCG) neurons, plus an analgesic effect on mice ${ }^{[49]}$.

\subsection{Marine neurotoxins interacting with other receptors}

Among the CTX family some toxins bind to the receptors in nerves and muscles, with high affinity and highly specific features. Thus they can be used as useful tools for neuroscience. Such as $\alpha$-CTX can acts on and blockades neuronal chondrocyte acetylcholine receptors (AchR) ${ }^{[51]}$.

Domoic acid (DA) is produced by a type of algae called Pseudo-nitzschia, which flourished in massive blooms due to above average water temperatures and high levels of nutrient runoff ${ }^{[52]}$. DA from algae induced sea lions death and is found in various commonly consumed commercial fish species ${ }^{[53]}$. Exposure to DA damages the spatial memory of sea lions. It is also the principal cause of amnesic shellfish poisoning (ASP) in human. DA behaves similarly to the neurotransmitter glutamic acid, binding to and eventually killing receptors in the hippocampus and causing short- and long-term memory loss in mammals, including humans ${ }^{[54]}$. Thus fast and effective method was developed to detect 
DA based upon microchip electrophoresis combined with laser-induced fluorescence detection ${ }^{[55]}$. It has been widely used as AMPA/kainate receptor agonist in neurotoxicity studies in learning and memory disease models ${ }^{[6,56,57]}$. Recent study indicate that DA induces long-term changes in a2-adrenoceptor binding in rat brain that may have relevance to the progression of an epilepsy phenotype ${ }^{[58]}$.

The neurotoxin $\beta-\mathrm{N}$-methylamino-L-alanine (BMAA) and its isomers 2,4-diaminobutyric acid (DAB) and N-2 (aminoethyl) glycine (AEG) are found in marine mollusks, probably produced by cyanobacteria ${ }^{[59]}$. BMAA has been hypothesized to trigger the pathogenesis of neurodegenerative diseases like Amyotrophic Lateral Sclerosis (ALS) and Alzheimer's disease (AD). Extensive in vitro experiments have demonstrated that the neurotoxicity of BMAA for neurons is a result of multiple mechanisms including action on glutamate receptors to induce oxidative stress in the neuron by depleting glutathione and generating a cytotoxic DNA damaging alkylating agent ${ }^{[60,61]}$. Study with vervets showed that BMAA may trigger neurodegenerative disease such as Alzheimer's Disease as a result of gene/environment interaction, thus it could became a useful tool for studying of neurodegenerative disease $[62,63]$. Because it is predicated that BMAA toxicity is transferrable from mother to infant, thus extra caution is in need within the areas where BMAA and its derivatives exist ${ }^{[64,65]}$. Method to detect BMAA level will facilitate prevention of BMAA toxicity ${ }^{[66]}$.

Nereistoxin (NTX) was originated from a marine annelid worm Lumbriconereis heteropoda. There have been reports about its neuronal toxicity in human and animal by blocking nicotinic acetylcholine receptor, and by reversibly inhibiting radio ligand binding to Torpedo nicotinic receptors ${ }^{[67,68]}$. It causes significant neuromuscular toxicity, that may result in respiratory failure. There is report that in chick retinas NTX blockaded retinal responses to the nicotinic agonist dimethylphenylpiperazinium ${ }^{[69]}$. NTX inhibition characterized of being selective for nicotinic receptors, long lasting, and not reversible upon washing. NTX or its metabolite is suggested to be a potent antagonist as well as a selective reducing agent for nicotinic receptors in chick retina. Its analogue pesticides including cartap, bensultap, thiocyclam, and thiobensultap have been commonly used in agriculture, because of their low toxicity and high insecticidal activity ${ }^{[70]}$.

Anabaseine is an alkaloid toxin produced by Nemertines. Due to its similar structure with nicotine, it has been shown to act as an agonist on most nicotinic acetylcholine receptors in the central nervous system and peripheral nervous system ${ }^{[71]}$. Binding of the receptors causes the depolarization of neurons and induces the release of both dopamine and norepinephrine. Compare to existing antipsychotic drugs, a7Nicotinic acetylcholine receptors have became as a potential therapeutic target for the treatment of neurocognitive dysfunctions in schizophrenia ${ }^{[72]}$. However its derivatives, such as 3- (2,4 dimethoxy) - benzylidene。-anabaseine (DMXB-A, known as GTS-21), with cytoprotector properties and improved memory in experimental animal of cognitive and memory deficits diseases ${ }^{[73]}$. Substances of this series are developed as potential drugs for treating Alzheimer's disease.

\section{CONCLUSION}

We summarized the mechanism of most popular marine neurotoxins by far and updated their pharmacology characters and applications in research. Research in marine neurotoxins is very important for people's health. Based on the current information about marine toxins, a platform should be established to detect the neurotoxicity of marine active substrates. It is important to monitor the safety of marine products. Studies investigating applications of marine toxins in neurodegenerative diseases, the development of biosensors is also of great interest. Marine neurotoxins can be used as experimental models, potential therapeutics, or neurobiological tools. As a conclusion, due to the unique features of marine neurotoxins and strong biological activities, they can play an important role in the brain science research and great potential for drug development.

\section{ACKNOWLEDGMENTS}

We thank Dr. Ying Xiao for discussion and editing the manuscript. This work is supported by National Natural Science Foundation of China (31502182), Zhejiang Science and Technology Program (2017F50018, 2017F50020), Zhejiang Ocean University "marine science" major project (20160107). The funders had no role in study design, data collection and analysis, decision to publish, or preparation of the manuscript.

\section{CONFLICTS OF INTEREST}

The authors declare that there is no conflict of interest regarding the publication of this paper. 


\section{REFERENCES}

1. Pelin M, Brovedani V, Sosa S, Tubaro A. Palytoxin-Containing Aquarium Soft Corals as an Emerging Sanitary Problem. Mar Drugs. 2016;14(2):33

2. Nicolas J, Hendriksen PJ, van Kleef RG, de Groot A, Bovee TF, Rietjens IM, Westerink RH. Detection of marine neurotoxins in food safety testing using a multielectrode array. Mol Nutr Food Res. 2014;58:2369-2378.

3. Watters MR: Tropical marine neurotoxins. venoms to drugs. Semin Neurol. 2005;25:278289.

4. Danysz W. Neurotoxicity as a mechanism for neurodegenerative disorders: basic and clinical aspects. Expert Opin Investig Drugs. 2001;10:985-989.

5. Patocka J, Gupta RC, Wu QH, Kuca K. Toxic potential of palytoxin. J Huazhong Univ Sci Tech Med Sci. 2015;35:773-780.

6. Archer T, Kostrzewa RM. Neuroteratology and Animal Modeling of Brain Disorders. Curr Top Behav Neurosci. 2016;29:1-40.

7. Catterall WA, Trainer V, Baden DG. Molecular properties of the sodium channel: a receptor for multiple neurotoxins. Bull Soc Pathol Exot. 1992;85:481-485.

8. Chau R, Kalaitzis JA, Wood SA, Neilan BA. Diversity and biosynthetic potential of culturable microbes associated with toxic marine animals. Mar Drugs. 2013;11:2695-2712.

9. Hanifin CT. The chemical and evolutionary ecology of tetrodotoxin (TTX) toxicity in terrestrial vertebrates. Mar Drugs. 2010;8:577593.

10. Yamada R, Tsunashima T, Takei M, Sato T, Wajima Y, Kawase M, Oshikiri S, Kajitani Y, Kosoba K, Ueda H, Abe K, Itoi S, Sugita H. Seasonal Changes in the Tetrodotoxin Content of the Flatworm Planocera multitentaculata. Mar Drugs. 2017;15(3):pii: E56.

11. Conejo NM, Cimadevilla JM, Gonzalez-Pardo H, Mendez-Couz M, Arias JL. Hippocampal inactivation with TTX impairs long-term spatial memory retrieval and modifies brain metabolic activity. PLoS One. 2013;8:e64749.

12. Carrasco DI, Vincent JA, Cope TC. Distribution of TTX-sensitive voltage-gated sodium channels in primary sensory endings of mammalian muscle spindles. J Neurophysiol. 2017; jn.00889.2016.
13. Lin JW. Spatial gradient in TTX sensitivity of axons at the crayfish opener neuromuscular junction. J Neurophysiol. 2013;109:162-170.

14. Nieto FR, Cobos EJ, Tejada MA, SanchezFernandez C, Gonzalez-Cano R, Cendan CM. Tetrodotoxin (TTX) as a therapeutic agent for pain. Mar Drugs. 2012;10:281-305.

15. Meyer L, Capper A, Carter S, Simpfendorfer C. An investigation into ciguatoxin bioaccumulation in sharks. Toxicon. 2016;119:234-243.

16. Martin V, Vale C, Hirama M, Yamashita S, Rubiolo JA, Vieytes MR, Botana LM. Synthetic ciguatoxin CTX $3 \mathrm{C}$ induces a rapid imbalance in neuronal excitability. Chem Res Toxicol. 2015;28:1095-1108.

17. Inserra MC, Israel MR, Caldwell A, Castro J, Deuis JR, Harrington AM, Keramidas A, GarciaCaraballo S, Maddern J, Erickson A, Grundy L, Rychkov GY, Zimmermann K, Lewis RJ, Brierley SM, Vetter I. Multiple sodium channel isoforms mediate the pathological effects of Pacific ciguatoxin-1. Sci Rep. 2017;7:42810.

18. Hogg RC, Lewis RJ, Adams DJ. Ciguatoxininduced oscillations in membrane potential and action potential firing in rat parasympathetic neurons. Eur J Neurosci. 2002;16:242-248.

19. Hamilton $B$, Hurbungs M, Vernoux JP, Jones $A$, Lewis RJ. Isolation and characterisation of Indian Ocean ciguatoxin. Toxicon. 2002;40:685693.

20. Doerr B, O'Halloran J, O'Brien N, van Pelt F. Investigation of the genotoxic potential of the marine biotoxins azaspiracid 1-3. Toxicon. 2016;121:61-69.

21. Kulagina NV, Twiner MJ, Hess $P$, McMahon T, Satake M, Yasumoto T, Ramsdell JS, Doucette GJ, Ma W, O'Shaughnessy TJ. Azaspiracid-1 inhibits bioelectrical activity of spinal cord neuronal networks. Toxicon. 2006;47:766-773.

22. Hjornevik LV, Froyset AK, Gronset TA, Rungruangsak-Torrissen K, Fladmark KE. Algal Toxin Azaspiracid-1 Induces Early Neuronal Differentiation and Alters Peripherin Isoform Stoichiometry. Mar Drugs. 2015;13:7390-7402.

23. Thangaraj S, Bragadeeswaran S, Srikumaran $\mathrm{N}$, Suguna A. Analgesic and CNS Depressant Activities of Sea Anemone Heteractis aurora Nematocyst Toxin. Cent Nerv Syst Agents Med Chem. 2016;16:167-172.

24. Standker L, Beress L, Garateix A, Christ $T$, Ravens $U$, Salceda E, Soto E, John $H$, Forssmann WG, Aneiros A. A new toxin from 
the sea anemone Condylactis gigantea with effect on sodium channel inactivation. Toxicon. 2006;48:211-220.

25. Moran Y, Gordon D, Gurevitz M. Sea anemone toxins affecting voltage-gated sodium channels-molecular and evolutionary features. Toxicon. 2009;54:1089-1101.

26. Klinger $A B$, Eberhardt $M$, Link AS, Namer $B$, Kutsche LK, Schuy ET, Sittl R, Hoffmann T, Alzheimer C, Huth T, Carr RW, Lampert A. Seaanemone toxin ATX-II elicits A-fiber-dependent pain and enhances resurgent and persistent sodium currents in large sensory neurons. Mol Pain. 2012;8:69.

27. Brand S, Seeger T, Alzheimer C. Enhancement of persistent $\mathrm{Na}^{+}$current by sea anemone toxin (ATX II) exerts dual action on hippocampal excitability. Eur J Neurosci. 2000;12:2387-2396.

28. Oliveira JS, Redaelli E, Zaharenko AJ, Cassulini RR, Konno K, Pimenta DC, Freitas JC, Clare JJ, Wanke E. Binding specificity of sea anemone toxins to Nav 1.1-1.6 sodium channels: unexpected contributions from differences in the IV/S3-S4 outer loop. J Biol Chem. 2004;279:33323-33335.

29. Cariello L, de Santis A, Fiore F, Piccoli R, Spagnuolo A, Zanetti L, Parente A. Calitoxin, a neurotoxic peptide from the sea anemone Calliactis parasitica: amino acid sequence and electrophysiological properties. Biochemistry. 1989;28:2484-2489.

30. Yin JB, Fan YX, Shen HB. Conotoxin superfamily prediction using diffusion maps dimensionality reduction and subspace classifier. Curr Protein Pept Sci. 2011;12:580-588.

31. Yang M, Zhao S, Min X, Shao M, Chen Y, Chen $Z$, Zhou M. A novel mu-conotoxin from wormhunting Conus tessulatus that selectively inhibit rat TTX-resistant sodium currents. Toxicon. 2017;130:11-18.

32. West PJ, Bulaj G, Yoshikami D. Effects of deltaconotoxins PVIA and SVIE on sodium channels in the amphibian sympathetic nervous system. J Neurophysiol. 2005;94:3916-3924.

33. Ferrer RP, Lunsford ET, Candido CM, Strawn ML, Pierce KM: Saxitoxin and the Ochre Sea Star: Molecule of Keystone Significance and a Classic Keystone Species. Integr Comp Biol 2015;55:533-542.

34. Boullot F, Castrec J, Bidault A, Dantas N, Payton L, Perrigault M, Tran D, Amzil Z, Boudry P, Soudant P, Hegaret H, Fabioux C. Molecular Characterization of Voltage-Gated
Sodium Channels and Their Relations with Paralytic Shellfish Toxin Bioaccumulation in the Pacific Oyster Crassostrea gigas. Mar Drugs. 2017;15(1): pii: E21.

35. Pratheepa V, Vasconcelos V. Binding and Pharmacokinetics of the Sodium Channel Blocking Toxins (Saxitoxin and the Tetrodotoxins). Mini Rev Med Chem. 2016;17(4):320-327.

36. Pomati F, Rossetti C, Calamari D, Neilan BA. Effects of saxitoxin (STX) and veratridine on bacterial $\mathrm{Na}^{+}$- $\mathrm{K}^{+}$fluxes: a prokaryotebased STX bioassay. Appl Environ Microbiol. 2003;69:7371-7376.

37. Ajani P, Harwood DT, Murray SA. Recent Trends in Marine Phycotoxins from Australian Coastal Waters. Mar Drugs. 2017;15(2):33.

38. Bire R, Trotereau S, Lemee R, Oregioni D, Delpont C, Krys S, Guerin T. Hunt for Palytoxins in a Wide Variety of Marine Organisms Harvested in 2010 on the French Mediterranean Coast. Mar Drugs. 2015;13:5425-5446.

39. Kuang Q, Purhonen $P$, Hebert H: Structure of potassium channels. Cell Mol Life Sci. 2015;72:3677-3693.

40. Orts DJ, Peigneur S, Madio B, Cassoli JS, Montandon GG, Pimenta AM, Bicudo JE, Freitas JC, Zaharenko AJ, Tytgat J. Biochemical and electrophysiological characterization of two sea anemone type 1 potassium toxins from a geographically distant population of Bunodosoma caissarum. Mar Drugs. 2013;11:655-679.

41. Liu P, Jo S, Bean BP. Modulation of neuronal sodium channels by the sea anemone peptide BDS-I. J Neurophysiol. 2012;107:3155-3167.

42. Yeung SY, Thompson D, Wang Z, Fedida D, Robertson B. Modulation of Kv3 subfamily potassium currents by the sea anemone toxin BDS: significance for CNS and biophysical studies. J Neurosci. 2005;25:8735-8745.

43. Diochot S, Lazdunski M. Sea anemone toxins affecting potassium channels. Prog Mol Subcell Biol. 2009;46:99-122.

44. Schweitz H, Bruhn T, Guillemare E, Moinier D, Lancelin JM, Beress L, Lazdunski M. Kalicludines and kaliseptine. Two different classes of sea anemone toxins for voltage sensitive $\mathrm{K}^{+}$channels. J Biol Chem. 1995;270:25121-25126.

45. Simms BA, Zamponi GW. Neuronal voltagegated calcium channels: structure, function, and 
dysfunction. Neuron. 2014;82:24-45.

46. Gandini MA, Sandoval A, Felix R. Toxins targeting voltage-activated $\mathrm{Ca}^{2+}$ channels and their potential biomedical applications. Curr Top Med Chem. 2015;15:604-616.

47. Diniz DM, de Souza AH, Pereira EM, da Silva JF, Rigo FK, Romano-Silva MA, Binda N, Castro CJ, Cordeiro MN, Ferreira J. Gomez MV. Effects of the calcium channel blockers Phalpha1beta and omega-conotoxin MVIIA on capsaicin and acetic acid-induced visceral nociception in mice. Pharmacol Biochem Behav. 2014;126:97-102.

48. Lee S, Kim Y, Back SK, Choi HW, Lee JY, Jung $\mathrm{HH}$, Ryu JH, Suh HW, Na HS, Kim HJ, Rhim $\mathrm{H}$, Kim Jl. Analgesic effect of highly reversible omega-conotoxin FVIA on $\mathrm{N}$ type $\mathrm{Ca}^{2+}$ channels. Mol Pain. 2010;6:97.

49. Bernaldez J, Roman-Gonzalez SA, Martinez O, Jimenez S, Vivas O, Arenas I, Corzo G, Arreguin R, Garcia DE, Possani LD, Licea A. A Conus regularis conotoxin with a novel eight-cysteine framework inhibits CaV2.2 channels and displays an anti-nociceptive activity. Mar Drugs. 2013;11:1188-1202.

50. Hannon HE, Atchison WD. Omega-conotoxins as experimental tools and therapeutics in pain management. Mar Drugs. 2013;11:680-699.

51. Abraham N, Healy M, Ragnarsson L, Brust A, Alewood PF, Lewis RJ. Structural mechanisms for alpha-conotoxin activity at the human alpha3beta4 nicotinic acetylcholine receptor. Sci Rep. 2017;7:45466.

52. Pulido OM. Domoic acid toxicologic pathology: a review. Mar Drugs. 2008;6:180-219.

53. Cook PF, Reichmuth C, Rouse A, Dennison S, Van Bonn B, Gulland F. Natural exposure to domoic acid causes behavioral perseveration in Wild Sea lions: Neural underpinnings and diagnostic application. Neurotoxicol Teratol. 2016;57:95-105.

54. Hortiguela MJ, Wall JG. Improved detection of domoic acid using covalently immobilised antibody fragments. Mar Drugs. 2013;11:881895.

55. Cheng Y, Guo C, Zhao B, Yang L. Fast analysis of domoic acid using microchip electrophoresis with laser-induced fluorescence detection. J Sep Sci. 2017;40(7):1583-1588.

56. Motaghinejad M, Motevalian M, Fatima S. Mediatory role of NMDA, AMPA/kainate, GABAA and Alpha2 receptors in topiramate neuroprotective effects against methylphenidate induced neurotoxicity in rat. Life Sci.
2017;179:37-53

57. More SV, Kumar H, Cho DY, Yun YS, Choi DK. Toxin-Induced Experimental Models of Learning and Memory Impairment. Int J Mol Sci. 2016;17(9):1447

58. Thomsen MB, Lillethorup TP, Jakobsen S, Nielsen EH, Simonsen M, Wegener G, Landau AM, Tasker RA: Neonatal domoic acid alters in vivo binding of $11 \mathrm{C}$ 。 yohimbine to alpha2-adrenoceptors in adult rat brain. Psychopharmacology (Berl) 2016;233:37793785.

59. Reveillon D, Sechet V, Hess P, Amzil Z. Production of BMAA and DAB by diatoms (Phaeodactylum tricornutum, Chaetoceros sp., Chaetoceros calcitrans and, Thalassiosira pseudonana) and bacteria isolated from a diatom culture. Harmful Algae. 2016;58:45-50.

60. Li A, Song J, Hu Y, Deng L, Ding L, Li M. New Typical Vector of Neurotoxin beta-NMethylamino-I-Alanine (BMAA) in the Marine Benthic Ecosystem. Mar Drugs. 2016;14(11):202

61. Potjewyd G, Day PJ, Shangula S, Margison GP, Povey AC. L-beta-N-methylamino-I-alanine (BMAA) nitrosation generates a cytotoxic DNA damaging alkylating agent: An unexplored mechanism for neurodegenerative disease. Neurotoxicology. 2017;59:105-109.

62. Petrozziello T, Secondo A, Tedeschi V, Esposito A, Sisalli M, Scorziello A, Di Renzo G, Annunziato L. ApoSOD1 lacking dismutase activity neuroprotects motor neurons exposed to beta-methylamino-L-alanine through the $\mathrm{Ca}^{2+}$ / Akt/ERK1/2 prosurvival pathway. Cell Death Differ. 2017;24:511-522.

63. D'Mello F, Braidy N, Marcal H, Guillemin G, Rossi F, Chinian M, Laurent D, Teo C, Neilan BA. Cytotoxic Effects of Environmental Toxins on Human Glial Cells. Neurotox Res. 2017;31:245258.

64. Andersson M, Ersson L, Brandt I, Bergstrom U. Potential transfer of neurotoxic amino acid beta$\mathrm{N}$-methylamino-alanine (BMAA) from mother to infant during breast-feeding: Predictions from human cell lines. Toxicol Appl Pharmacol. 2017;320:40-50.

65. Powers S, Kwok S, Lovejoy E, Lavin T, Sher R. Embryonic Exposure to the Environmental Neurotoxin BMAA Negatively Impacts Early Neuronal Development and Progression of Neurodegeneration in the Sod1-G93R Zebrafish Model of Amyotrophic Lateral Sclerosis. Toxicol Sci. 2017;157(1):129-140 
66. Porojan C, Mitrovic SM, Yeo DC, Furey A. Overview of the potent cyanobacterial neurotoxin beta-methylamino-L-alanine (BMAA) and its analytical determination. Food Addit Contam Part A Chem Anal Control Expo Risk Assess. 2016;33:1570-1586.

67. Eldefrawi AT, Bakry NM, Eldefrawi ME, Tsai MC, Albuquerque EX. Nereistoxin interaction with the acetylcholine receptor-ionic channel complex. Mol Pharmacol. 1980;17:172-179.

68. Chiba S, Nagawa Y. Effects of nereistoxin and its derivatives on the spinal cord and motor nerve terminals. Jpn J Pharmacol. 1971;21:175184.

69. Xie Y, Lane WV, Loring RH. Nereistoxin: a naturally occurring toxin with redox effects on neuronal nicotinic acetylcholine receptors in chick retina. J Pharmacol Exp Ther. 1993;264:689-694.

70. Lee SJ, Tomizawa M, Casida JE. Nereistoxin and cartap neurotoxicity attributable to direct block of the insect nicotinic receptor/channel. J Agric Food Chem. 2003;51:2646-2652.

71. Rosse G: Anabaseine analogues as modulators of nicotinic acetylcholine receptor. ACS Med Chem Lett. 2013;4:902-903.

72. Freedman R. alpha7-nicotinic acetylcholine receptor agonists for cognitive enhancement in schizophrenia. Annu Rev Med. 2014;65:245261.

73. Briggs CA, Anderson DJ, Brioni JD, Buccafusco JJ, Buckley MJ, Campbell JE, Decker MW, Donnelly-Roberts D, Elliott RL, Gopalakrishnan M, Holladay MW, Hui YH, Jackson WJ, Kim DJ, Marsh KC, O'Neill A, Prendergast MA, Ryther KB, Sullivan JP, Arneric SP. Functional characterization of the novel neuronal nicotinic acetylcholine receptor ligand GTS-21 in vitro and in vivo. Pharmacol Biochem Behav. 1997;57:231-241. 